\title{
Strategy for Development of Counseling Guidelines in Basic Schools in Dealing With Millennial 4.0 Era
}

\section{Idzaa Zubdatun Thoyyibah, Apriliani Indah Sari}

Universitas Sebelas Maret

zubdatunidzaa@gmail.com

\section{Article History}

accepted 24/09/2019

approved 01/10/2019

published 01/12/2019

\begin{abstract}
In this era of guidance and counseling services in primary schools requires a better strategy. Therefore, this paper aims to describe the strategy of guidance and counseling in schools to deal with millennial generation 4.0. Guidance and counseling services that have received updates or innovations in their implementation certainly can overcome the problems that are being faced by students. This research uses the literature study method and the data collected is obtained from journals that are in accordance with this research. Literature sources obtained from journals, research, and books. This research includes the process of identifying theories that are prepared systematically, finding literature, and analyzing documents that contain information that is relevant to the research topic. The results of this study are in the form of strategies for developing guidance and counseling in elementary schools to deal with the milineal 4.0 era.
\end{abstract}

Keywords: Strategy, Counseling Guidance, Millennial Era

\begin{abstract}
Abstrak
Pada era sekarang pelayanan bimbingan dan konseling di sekolah dasar memerlukan startegi yang lebih baik. Oleh karena itu, dalam penulisan ini bertujuan untuk mendeskripsikan strategi bimbingan dan konseling di sekolah untuk menghadapi generasi milenial 4.0. Layanan bimbingan dan konseling yang sudah mendapat pembaharuan atau inovasi dalam pengimplementasiannya tentu dapat mengatasi permasalahan-permasalahan yang sedang dihadapi oleh siswa. Penelitian ini menggunakan metode studi literatur dan data yang dikumpulkan didapat dari jurnal-jurnal yang sesuai dengan penelitian ini. Sumber literatur diperoleh dari jurnal, penelitian, dan buku. Penelitian ini mencakup proses mengidentifikasi teori yang disusun secara sistematis, menemukan literatur, dan menganalisis dokumen yang berisi informasi yang sesuai dengan topik penelitian. Hasil penelitian ini berupa strategi pengembangan bimbingan dan konseling di sekolah dasar untuk menghadapi era milineal 4.0 Kata kunci :Strategi, Bimbingan Konseling, Era Milenial
\end{abstract}

Social, Humanities, and Education Studies (SHEs): Conference Series https://jurnal.uns.ac.id/shes

p-ISSN 2620-9284

e-ISSN 2620-9292 


\section{PENDAHULUAN}

Pada era sekarang IPTEK sudah berpengaruh pesat terhadap perubahan diberbagai aspek kehidupan. Posisi masyarakat sekarang dituntut untuk bisa menyesuaikan dengan perubahan yang telah terjadi, jika tidak bisa ikut untuk mengubah dirinya di era sekarang maka akan tertinggal dan sulit mengalami perubahan. Manusia yang berkompetensi dan produktif tentu dapat menyesuaikan dengan zaman (Bahkti dan Safitri, 2017: 105). Perubahan yang terjadi juga berpengaruh terhadap bidang pendidikan yang dapat menciptakan manusia berkualitas dan mengubahnya ke arah yang lebih baik. Oleh karena itu, baik keluarga maupun sekolah harus melakukan upaya untuk penyiapkan manusia berkualitas, yaitu manusia yang kreatif dan inovasi di era revolusi 4.0. Menurut Juntika (2011) pendidikan yang bermutu ialah pendidikan yang dapat memberikan perubahan yang positif untuk peserta didik pada saat ini ataupun di masa mendatang. Untuk menciptakan pendidikan yang berkualitas maka perlu adanya dukungan dan pengembangan kemampuan dalam diri individu. Pengembangan kemampuan seorang individu dapat diciptakan melalui lingkungan terdekat. Lingkungan berpengaruh terhadap pembentukan karakter anak. Lingkungan yang dimaksud yaitu lingkungan sekolah dan tidak luput juga lingkungan keluarga serta lingkungan masyarakat yang dapat membentuk kepribadian anak. Sekolah merupakan tempat untuk mendidik, membentuk karakter anak, dan sebagai agen perubahan anak menuju kearah yang lebih baik serta sekolah didukung oleh para orang tua dan masyarakat.

Sekolah mempunyai layanan bimbingan dan konseling yang diberikan kepada seluruh peserta didik yang digunakan untuk pengembangan potensi, pembentukan karakter, dan perubahan peserta didik kearah yang lebih baik. Pemberian layanan bimbingan dan konseling tidak hanya diberikan di SMP atau SMA saja, tetapi di SD (Sekolah Dasar) juga terdapat layanan BK yang disalurkan melalui guru kelas kepada siswa secara langsung. Menurut Hamalik, (1992), BK sangat dibutuhkan di sekolah/ madrasah karena saat ini perkembangan teknologi informasi, dan komunikasi berkembang sangat pesat yang tentunya mempengaruhi masyarakat secara universal (Tohirin, 2013: 12). Dunia pendidikan telah dipengaruhi oleh adanya perkembangan IPTEK. Oleh sebab itu sekolah dan pemerintah perlu menyikapi adanya perubahan yang cepat tersebut dengan melakukan pembaharuan dalam aspek kurikulum maupun strategi dalam pembelajaran yang lebih canggih. Selain kedua aspek dalam pendidikan tersebut yang diubah tentu akan lebih baik jika di sekolah dasar khususnya ada strategi BK baru untuk para guru dan peserta didik. BK sangat berkontribusi dalam pelaksanaan pendidikan di sekolah. Keberhasilan dalam proses pendidikan di sekolah/madrasah diperoleh karena adanya dukungan dari para penyelenggara bimbingan/konseling yang sukses dalam pengimplementasiannya. Sekolah/madrasah berkontribusi besar dan bertanggung jawab dalam menciptakan siswa yang berkualitas dan berkompetensi. Oleh karena itu. sekolah/madrasah harus memberikan layanan BK yang baik untuk siswa yang dapat digunakan untuk mengatasi permasalahan yang terjadi dalam proses pembelajaran. Dalam situasi yang seperti ini layanan bimbingan dan konseling sangat penting untuk membantu siswa dalam mengatasi berbagai masalah yang terjadi di sekolah ataupun di luar sekolah.

Permasalahan umum yang terjadi pada individu khususnya oleh siswa sekolah dasar yang memerlukan layanan bimbingan dan konseling adalah: (I) masalah yang berkaitan dengan diri sendiri/pribadi, (2) kesulitan dalam belajar, (3) pendidikan yang masih belum menetapkan kurikulum yang jelas, (4) masalah karier, (5) pemanfaatan waktu yang senggang, (6) masalah sosial, dan lain-lain. Saat ini banyak perilaku peserta didik pada usia SD atau masih tergolong anak-anak ini yang dapat menghambatnya untuk mengembangkan potensi yang dimilikinya maupun dalam pembentukan karakternya. Peserta didik pada usia SD juga sering menemukan hambatan dan permasalahan yang belum bisa diselesiakan sendiri dan membuat 
mereka bergantung kepada teman lain, orang tua, guru kelas, atau diam menyendiri. Perkembangan IPTEK khususnya media elektronik ataupun media cetak telah membawa banyak fenomena negatif yang terjadi pada siswa SD mulai dari kekerasan seksual, merokok, tawuran, dan sebagainya. Dalam permasalahan tersebut, guru kelas tidak dapat bergerak sendiri untuk membantu menyelesaikan masalah tersebut tetapi diperlukan orang yang berkeahlian di bidang bimbingan dan konseling. Oleh sebab itu bimbingan/konseling merupakan suatu komponen yang harus ada di sekolah khususnya di sekolah dasar untuk membantu guru kelas dalam menyelesaikan masalah-masalah yang diterjadi pada peserta didik. BK juga diperuntukan dapat membentuk peserta didik yang lebih berkualitas, membentuk karakter yang baik, dan dapat mengembangkan potensi peserta didik.

Berdasarkan latar belakang tersebut penulis mencoba untuk menguraikan sebuah tulisan/artikel yang menjelaskan tentang stategi pengembangan layanan bimbingan dan konseling di Sekolah Dasar dalam menghadapi era milenial 4.0. Penulisan ini bertujuan untuk mendeskripsikan stategi pengembangan bimbingan konseling di sekolah dasar dalam menghadapi era milenial 4.0.

\section{METODE}

Penelitian ini menggunakan metode penelitian yang berupa studi kepustakaan, Nazir (2003) berpendapat bahwa, "studi kepustakaan adalah teknik pengumpulan data dengan mengadakan studi penelaahan terhadap buku-buku, literatur-literatur, catatancatatan, dan laporan-laporan yang ada hubungannya dengan masalah yang dipecahkan". Kajian teori dilakukan oleh peneliti sesuai dengan teori yang besangkutan dan data penelitian diperoleh melalui pengumpulan informasi dari jurnal-jurnal penelitian dan buku yang diuraikan secara sistematis.

\section{Konsep Bimbingan dan Konseling}

HASIL DAN PEMBAHASAN

Berdasarkan Peraturan Pemerintah No. 29/1990 tentang Pendidikan Menengah Pasal 27 Ayat 1, bahwa bimbingan merupakan bantuan yang diberikan kepada siswa dalam rangka upaya menemukan pribadi, mengenal lingkungan dan merencanakan masa depan. Sedangkan menurut Surat Keputusan Mendikbud No. 025/1995 tentang Petunjuk Pelaksanaan Jabatan Fungsional Guru dan Angka Kreditnya, menyebutkan bahwa Bimbingan dan Konseling (BK) adalah layanan bantuan untuk peserta didik, baik secara perorangan maupun kelompok, agar mandiri dan berkembang secara optimal, dalam bimbingan pribadi, bimbingan sosial, bimbingan belajar dan bimbingan karir, melalui berbagai jenis layanan dan kegiatan pendukung berdasarkan normanorma yang berlaku.

Menurut Azzet (2013:11), bimbingan dan konseling adalah upaya pemberian bantuan kepada anak didik agar dapat memahami dirinya sehingga sanggup mengarahkan diri dan bertindak dengan baik sesuai dengan perkembangan jiwanya. Dari pengertian di atas dapat disimpulkan bahwa bimbingan dan konseling adalah pelayanan yang diperuntukan bagi siswa dalam memahami diri dan bertindak baik sesuai dengan perkembangan jiwanya.

\section{Strategi Pengembangan Bimbingan Konseling di Sekolah Dasar Dalam Menghadapi Era Milineal 4.0}

Peserta didik di era milenial mempunyai karakteristik yang berbeda dengan era sebelumnya. Peserta didik di era ini telah berpengalaman menggunakan teknologi digital untuk mencari informasi, media jejaring sosial, melihat dan mempublikasikan pesan. Dengan adanya kemajuan teknologi yang berkembang memberikan dampak negatif yaitu peserta didik terkena informasi overload, peserta didik menjadi malas 
untuk belajar dst. Dengan adanya hal itu peran layanan dan bimbingan konseling di sekolah dasar perlu dioptimalkan oleh guru kelas.

Peran guru dalam dunia pendidikan tidak hanya mengajarkan materi saja, akan tetapi juga berperan sebagai konselor. Hal tersebut sesuai dengan Permendiknas No 16 tahun 2009 pada bab VII yang menyatakan bahwa kegiatan guru kelas salah satunya yaitu melaksanakan Bimbingan dan Konseling di kelas yang menjadi tanggung jawabnya. Guru diharapkan dapat melaksanakan bimbingan dan konseling bagi siswa. Sesuai dengan Peraturan Pemerintah Pemendikbud No. 111 tahun 2014 tentang Penyelenggaraan Program Layanan Bimbingan dan Konseling di Tingkat Pendidikan Dasar dan Menengah. Guru diharapkan dapat memfasilitasi siswa agar dapat mengembangkan potensi yang dimiliki terkait dengan aspek fisik, emosi, intelektual, sosial, dan moral spiritual.Pada tingkatan dasar guru Sekolah Dasar dalam melayani peserta didik yang berkaitan dengan Progam Bimbingan dan Konseling di tangani langsung oleh guru kelas, mata pelajaran dan kepala sekolah. BK di SD tidak berdiri sendiri tetapi terinduksi dalam kegiatan belajar mengajar dalam kelas. Menurut Sanjaya (2014: 27) ada beberapa peran guru dalam pembelajaran, salah satunya yaitu sebagai pendidik Guru dituntut untuk dapat membimbing peserta didiknya sehingga mambu menemukan bakat dan minat serta potensi yang dimiliki peserta didik dan melaksanakan tugas perkembangan dengan baik. Adanya karakter siswa yang beragam tentunya menuntut guru untuk dapat membimbing dan memberikan kondidi pembelajaran yang baik sesuai dengan kebutuhan siswa.

Selain guru sebagai pembimbing dalam kegiatan pembelajaran, guru juga mengemban tugas menjadi seorang konsultan dalam pelayanan bimbingan dan konseling. Oleh karena itu guru juga harus mempunyai wawasan pengetahuan terkait bimbingan dan konseling. Hal ini tertera pada Keputusan Pengurus Besar Asosiasi Bimbingan dan Konseling Indonesia (ABKIN) Nomor: 010 tahun 2006 tentang Penetapan Kode Etik Bimbingan dan Konseling dalam Komalasari (2011: 10). Dalam kode etik ini menyebutjkan bahwa konselor diwajibkan mempunyai kualifikasi yaitu Nilai, Sikap, Ketrampilan, pengetahuan dan wawasan. Namun realitanya guru hanya focus pada pembelajaran tanpa memperhatikan kondisi peserta didik. Dengan beragamnya karakter peserta didik yang beranekaragam guru kerap sekali mengalami kesulitan dalam membimbing dan mengkondisikan peserta didiknya. Masalah yang sering muncul dalam pembelajaran bersumber dari individu peserta didiknya. Semisal ketika guru mengajar ada siswa yang ramai sendiri dan sulit untuk diatur. Hal tersebut mencul karena berbagai faktor. Salah satunya dari kondisi psikologis peserta didiknya. Peserta didik yang kurang mendapatkan perhatian dari orangtua ata sedang memiliki masalah dalam keluarga seringkali mencari perhatian saat di sekolah. Kondisi hal tersebut dapat mempengaruhi jalannya pembelajaran.

Menurut Lutfiyani, V. dan Bhakti, C.P. ( 2017) struktur pengembangan Bimbingan dan Konseling terdiri dari empat komponen yaitu (1) layanan dasar; (2) layanan responsif; (3) layanan peminatan dan perencanaan individual; (4) dukungan sistem, komponen dukungan sistem lebih diarahkan pada pemberian layanan dan kegiatan manajemen yang tidak secara langsung bermanfaat bagi siswa. Dukungan sistem di sekolah dasar mencakup : Konsultasi dengan guru-guru, dukungan bagi program pendidikan orang tua dan upaya-upaya masyarakat yang berhubungan, partisispasi dalam kegiatan sekolah dalam rangka peningkatan perencanaan dan tujuan, implementasi dan program standarisasi instrumen tes, kerja sama dalam melakukan riset yang relevan, memberikan masukan terhadap pembuat keputusan dalam kurikulum pengajaran, berdasarkan perspektif siswa.

Strategi yang dapat dilakukan dalam pengembanganpelayanan bimbingan dan konseling di SD dapat dilakukan dengan berbagai cara yaitu (1) memberikan pelatihan atau workshop terkait layanan bimbingan dan konseling kepada guru Sekolah Dasar. Jika diadakannya kegiata tersebut maka guru dapat melaksanakan pelayanan 
bimbingan dan konseling dengan baik, karena sudah memiliki bekal menjadi konselor dalam pembelajaran di kelas. (2) memberikan fasilitas pendamping analisis dan penyusunan progam BK, guru didampingi menganalisis kondisi kelas secara keseluruhan. Pendampingan ini tidak hanya dilakukan secara off line atau tatap muka secara langsung, akan tetapi guru dapat melakukan kegiatan pendampingan melalui media sosial (on-line). Hal tersebut akan memudahkan baik guru maupun pendamping dalam melakukan kegiatan menganalisis kondisi kelas. Guru akan diberikan link googleform yang berisi tentang masalah apa yang muncul dalam kelas, bagaimana kondisi kelas saat pembelajaran dan penyusunan progam dapat dikonsultasikan melalui email. (3) guru mengimplementasikan penyusunan progam BK, guru akan menerapkan pengetahuan, menganalisis kondisi kelas dan membuat rancangan progam yang sesuai dengan permasalahan yang muncul di kelas. Hal tersebut sejalan dengan penilitian Kusumaningtyas, D.I., Kumalasani, M.P., dan T Deviana, T. (2019) melakukan pengabdian di SD 8 Muhammadiyah Kota Malang sebagai solusi untuk mengatasi permasalahan yang muncul di dalam kelas yaitu melakukan workshop peran guru SD dalam layanan bimbingan dan konseling. Dengan diadakan kegiatan tersebut diharapkan guru SD dapat menemukan progam BK yang dapat digunakan dalam kegiatan pembelajaran sesuai dengan kebutuhan.

\section{SIMPULAN}

Berdasarkan uraian tersebut dapat disimpulakan bahwa strategi pengembangan layanan bimbingan dan konseling di SD dalam menghadapi era milenal 4.0 yaitu (1) guru SD di berikan pelatihan mengenai layanan Bimbingan dan Konseling. (2) guru diberikan fasilitas pendampingan analisis dan penyusunan progam BK baik tatap muka ataupun on- line (3) guru mengimplementasikan penyusunan dan menerapkan progam BK meliputi pengembangan, pengetahuan, menganalisis kondisi kelas serta dapat menangani permasalahan yang muncul di kelas.

\section{DAFTAR PUSTAKA}

Azzet, A.M. (2013). Bimbingan \& Konseling di Sekolah. Jogjakarta: Ar-Ruzz Media.

Bakti, P.C dan Safitri, E.N, (2017). Peran Bimbingan Dan Konseling Untuk Menghadapi Generasi Z Dalam Perspektif Bimbingan Dan Konseling Perkembangan. Jurnal Konseling GUSJIGANG Vol. 3 No. 1 (Januari-Juni 2017).

Juntika. (2011). Membangun Peradaban Bangsa Indonesia Melalui Pendidikan dan Komprehensif Bermutu. Disampaikan dalam pidato Pengukuhan Prof. Dr. $H$. Juntika, M.Pd sebagai GuruBesar/Profesor dalam Bidang Bimbingan dan Konseling.Pada Fakultas IImu Pendidikan Universitas Pendidikan Indonesia.

Komalasari, Gantina, dkk. (2011). Teori dan Teknik Konseling. PT Indeks: Jakarta

Kusumaningtyas, D.I., Kumalasani, M.P., dan T Deviana, T. (2019) Peran Guru SD dalam Memberikan Layanan Bimbingan dan Konseling Di SD Muhammadiyah 8 Kota Malang. Jurnal ABDINUS : Jurnal Pengabdian Nusantara, 2 (2), 2019,207214

Lutfiyani, V. dan Bhakti, P.C. (2017). Strategi Layanan Bimbingan dan Konseling Komprehensif dalam Pengembangan Self-Knowledge pada Siswa Sekolah Dasar. Jurnal SENDIKA, November 2017, Volume I, Nomor 1 Lutfiyani:370-377

Nazir, M. (2003). Metode Penelitian. Jakarta: Ghalia Indonesia Nur

Peraturan Mentri Pendidikan dan Kebudyaan RI Nomor 111 tahun 2014 tentang bimbingan dan konseling pada pendidikan dasar dan pendidikan menegah.

Permendiknas No.16.2009.Tentang Jabatan Fungsional Guru dan Angka Kreditnya.

Sanjaya, Wina. 2014.Strategi Pembelajaran Berorientasi Standar proses Pendidikan. Jakarta: Kencana.

Tohirin, (2013). Bimbingan dan Konseling di Sekolah dan Madrasah. Jakarta: PT Raja Grafindo Persada. 